\title{
PROSPEK PEMANFAATAN ALGA LAUT UNTUK INDUSTRI
}

\author{
(fah Munifah*)
}

\begin{abstract}
ABSTRAK
Sebagai negara maritim, Indonesia memiliki keragaman hayati yang berlimpah di antaranya berbagai jenis rumput laut atau makroalga, yang lazim disingkat dengan alga. Salah satu substansi kimia dari rumput laut yang bermanfaat adalah karbohidrat berupa polisakarida seperti alginat, karagenan, dan agar, sedangkan komponen penting lainnya adalah protein, lemak, dan vitamin yang semuanya merupakan metabolit primer. Metabolit primer tersebut telah banyak dimanfaatkan untuk bahan baku industri, makanan tambahan, sayuran, dan bahan obat-obatan guna memenuhi kebutuhan di dalam negeri dan untuk diekspor. Di samping itu, alga juga merupakan sumber senyawa bioaktif, yang merupakan metabolit sekunder yang memiliki aktivitas seperti antibakteri, antitumor, antiinflamasi, dan lain-lain. Pemanfaatan metabolit primer dari alga telah cukup berkembang namun pemanfaatan metabolit sekundernya hingga saat ini masih terbatas.
\end{abstract}

KATA KUNCI: alga laut, prospek, industri

\section{PENDAHULUAN}

Indonesia merupakan salah satu negara yang kaya akan jenis tumbuhan tingkat tinggi yang jumlahnya diperkirakan mencapai sekitar 25.000 jenis atau lebih dari $10 \%$ dari jenis flora dunia. Di samping itu, masih terdapat tumbuhan tingkat rendah berupa lumut dan gangang yang berjumlah \pm 35.000 jenis dengan $40 \%$ diantaranya merupakan jenis yang endemik atau hanya terdapat di Indonesia saja. Tingginya kekayaan alam dengan keanekaragaman tumbuhan yang dimiliki Indonesia itu memungkinkan untuk ditemukannya beraneka jenis senyawa kimia, karena semakin tinggi tingkat evolusi dari suatu tanaman, maka keanekaragaman molekul dari tumbuhan tersebut juga beragam (Widjihati, 2004).

Indonesia juga telah dikenal luas sebagai negara kepulauan yang dua pertiga wilayahnya adalah lautan dan mempunyai garis pantai terpanjang di dunia yaitu \pm 81 ribu km. Di dalam lautan terdapat bermacammacam makhluk hidup baik berupa tumbuhan air maupun hewan air. Salah satu makhluk hidup yang tumbuh dan berkembang di laut adalah alga. Ditinjau secara biologi, alga merupakan kelompok tumbuhan berklorofil yang terdiri dari satu atau banyak sel dan berbentuk koloni. Di dalam alga terkandung bahanbahan organik seperti polisakarida, agarosa, hormon, vitamin, mineral, dan juga senyawa bioaktif. Agarosa merupakan jenis agar yang digunakan pada percobaan dan penelitian di bidang bioteknologi dan mikrobiologi. Sejauh ini, pemanfaatan alga sebagai komoditi perdagangan atau bahan baku industri masih relatif kecil jika dibandingkan dengan keanekaragaman jenis alga yang ada di Indonesia. Padahal komponen kimiawi yang terdapat dalam alga sangat bermanfaat sebagai bahan baku industri makanan, kosmetik, farmasi, dan lain-lain (Satari, 1996).

Rumput laut (makroalga) adalah ganggang alga (algae) yang berbentuk poliseluler dan hidup di laut. Menurut Winarno (1990) dalam Yunizal (2004), alga hijau dan biru banyak tumbuh di air tawar, sedangkan alga coklat dan merah hampir secara ekslusif tumbuh di laut sebagai habitatnya. Anggadiredja et al.(2006) menyatakan bahwa dari 782 jenis rumput laut Indonesia, hanya 18 jenis dari 5 genus (marga) yang sudah diperdagangkan. Dari kelima marga tersebut, hanya genus Euchema dan Gracillaria yang sudah dibudidayakan. Produksi rata-rata rumput laut Indonesia selama 5 tahun(1995-1999) sebesar 38.000 ton per tahun dipanen dari lahan seluas kurang lebih 2.500 ha (tambak dan laut). Dengan demikian, baru termanfaatkan sebesar $9,7 \%$ saja dari luas potensi lahan yang ada (Anggadiredja et al., 2006).

Sejumlah genus rumput laut yang telah mendapat pasar dalam perdagangan internasional, yaitu Gracillaria, Gelidium, Gelidella, dan Gelidiopsis sebagai bahan baku penghasil agar-agar (agarophytes), Euchema dan Hypnea sebagai bahan baku penghasil karagenan (carrageenophytes), serta Sargassum Laminaria dan Turbinaria sebagai bahan baku penghasil alginat (alghinophytes). Berbagai jenis alga seperti Griffithsia, Ulva, Enteromorpha, Gracillaria, Euchema, Kappaphycus telah dikenal luas sebagai sumber makanan seperti salad rumput laut atau sumber karagenan yang dibutuhkan oleh industri gel. Begitupun dengan Sargassum serta Chlorella/ Nannochloropsis yang telah dimanfaatkan sebagai

*) Peneliti pada Balai Besar Riset Pengolahan Produk dan Bioteknologi Kelautan dan Perikanan 
adsorben logam berat, dan Osmundaria, Hypnea, dan Gelidium sebagai sumber senyawa bioaktif, serta Laminariales atau Kelp dan Sargassum muticum yang mengandung senyawa alginat yang berguna dalam industri farmasi. Pemanfaatan berbagai jenis alga yang lain adalah sebagai penghasil bioetanol dan biodiesel ataupun sebagai pupuk organik (Satari, 1996).

Perkembangan industri rumput laut di Indonesia cukup menggembirakan tetapi produknya masih terbatas pada produk dasar (base products) bukan produk akhir yang langsung dapat dimanfaatkan oleh konsumen. Oleh karena itu, impor akan produk akhir rumput laut berupa senyawa hidrokoloidnya (karagenan, alginat, agar) masih terus berlanjut. Hal ini dikarenakan belum berkembangnya teknologi formulasi untuk menghasilkan end product. Kebutuhan senyawa hidrokoloid dalam negeri maupun luar negeri belum terpenuhi secara optimal. Hal ini tercermin dari masih tingginya impor ketiga hidrokoloid tersebut. Volume impor olahan rumput laut per tahun sekitar 596 ton agar-agar, 200 ton karagenan, dan 1.275 ton alginat (Anggadiredja et al., 2006). Jadi prospek industri rumput laut di Indonesia cukup menjanjikan untuk produk akhir yang siap pakai dengan penguasaan teknologi dan pemasaran yang tepat agar mampu meningkatkan ekspor dan mensubstitusi impor.

\section{ALGA LAUT SEBAGAI SUMBER MAKANAN}

Kandungan bahan-bahan organik yang terdapat dalam alga merupakan sumber mineral dan vitamin untuk produk agar-agar, salad rumput laut, dan karagenan. Potensi alga sebagai sumber makanan (terutama rumput laut) di Indonesia telah dimanfaatkan secara komersial dan secara intensif telah dibudidayakan terutama dengan teknik polikultur (antara ikan dan rumput laut).

\section{ALGA LAUT SEBAGAI SUMBER SENYAWA ALGINAT}

Alginat merupakan komponen dari dinding sel alga yang banyak dijumpai pada alga coklat (Phaeophycota). Senyawa ini merupakan heteropolisakarida dari hasil pembentukan rantai monomer asam manuronat dan asam gulunorat. Kandungan alginat dalam alga tergantung pada jenis alganya. Kandungan terbesar alginat $30-40 \%$ bobot kering) dapat diperoleh dari jenis Laminariales sedangkan dari jenis Sargassum muticum hanya mengandung 16-18\% bobot kering (Putra, 2006).

Kualitas alginat dibagi dalam 3 kelompok, yaitu industrial grade, food grade, dan pharmaceutical grade, yang memerlukan kualitas bahan baku dan proses ekstraksi berbeda sesuai dengan mutu yang diinginkan. Untuk memperoleh bahan baku yang berkualitas, umur panen harus cukup dan beberapa hal berikut harus dilakukan dengan baik yaitu teknik pemanenan, sortasi, pencucian, perendaman, pengeringan, dan penyimpanan (Yunizal, 2004).

Pemanfaatan senyawa alginat di dunia industri telah banyak dilakukan seperti natrium alginat dimanfaatkan oleh industri tekstil untuk memperbaiki dan meningkatkan kualitas bahan industri, serta kalsium alginat digunakan dalam pembuatan obatobatan. Senyawa alginat juga banyak digunakan dalam produk susu dan makanan yang dibekukan untuk mencegah pembentukan kristal es. Dalam industri farmasi, alginat digunakan sebagai bahan pembuatan pelapis kapsul dan tablet. Alginat juga digunakan dalam pembuatan bahan biomaterial untuk tehnik pengobatan seperti micro-encapsulation dan transplantasi sel (Khotimchenko \& Khotimchenko, 2004; Hellio et al., 2003).

\section{ALGA LAUT SEBAGAI ADSORBEN LOGAM BERAT}

Pemanfaatan sistem adsorpsi untuk pengambilan logam-logam berat dari perairan telah banyak dilakukan. Beberapa spesies alga telah ditemukan mempunyai kemampuan yang cukup tinggi untuk mengadsorpsi ion-ion logam, baik dalam keadaan hidup maupun dalam bentuk sel mati (biomassa). Berbagai penelitian telah membuktikan bahwa gugus fungsi yang terdapat dalam alga mampu melakukan pengikatan dengan ion logam. Gugus fungsi tersebut terutama adalah gugus karboksil, hidroksil, sulfidril, amino, imidazol, sulfat, dan sulfonat yang terdapat di dinding sel dalam sitoplasma (Putra, 2006).

Menurut Harris \& Ramelow (1990), kemampuan alga dalam menyerap ion-ion logam sangat dibatasi oleh beberapa kelemahan seperti ukurannya yang sangat kecil, berat jenisnya yang rendah, dan mudah rusak karena degradasi oleh mikroorganisme lain. Untuk mengatasi kelemahan tersebut berbagai upaya telah dilakukan, diantaranya dengan mengimobilisasi biomassanya. Imobilisasi biomassa dapat dilakukan dengan mengunakan (1) matrik polimer seperti polietilena glikol dan akrilat, (2) oksida (oxides) seperti alumina dan silika, (3) campuran oksida (mixed oxides) seperti kristal aluminasilikat dan asam polihetero, serta (4) karbon (Augusto \& Pesso^a, 2003).

Berbagai mekanisme yang berbeda telah dipostulasikan untuk ikatan antara logam dengan alga/ biomassa seperti pertukaran ion, pembentukan 
kompleks koordinasi, penyerapan secara fisik, serta gugus fungsi aktif dari alga/biomassa seperti karboksil, sulfat, sulfonat, dan amina yang akan berikatan dengan ion logam (Augusto \& Pesso^a, 2003).

\section{ALGA LAUT SEBAGAI SUMBER SENYAWA BIOAKTIF}

Alga hijau, alga merah, ataupun alga coklat merupakan sumber potensial senyawa bioaktif yang sangat bermanfaat bagi pengembangan industri farmasi misalnya sebagai antibakteri, antitumor, antikanker, sebagai reversal agent, serta dalam industri agrokimia yaitu sebagai antibakteri, antifeedant, antifouling, antiinflamasi, fungisida, dan herbisida.

Kemampuan alga untuk memproduksi metabolit sekunder terhalogenasi yang bersifat sebagai senyawa bioaktif dimungkinkan terjadi, karena kondisi lingkungan hidup alga yang ekstrim seperti salinitas yang tinggi atau sebagai upaya untuk mempertahankan diri dari ancaman predator. Dalam dekade terakhir ini, berbagai variasi struktur senyawa bioaktif yang sangat unik dari isolat alga merah telah berhasil diisolasi. Namun pemanfaatan sumber bahan bioaktif dari alga belum banyak dilakukan. Berdasarkan proses biosintesisnya, alga laut kaya akan senyawa turunan dari oksidasi asam lemak yang disebut oksilipin. Melalui senyawa ini berbagai jenis senyawa metabolit sekunder diproduksi (Konig et al., 1994).

Ma Jing Wend \& Tan Wei-ci (1984) dalam Yunizal (2004), telah melakukan penelitian tentang aktivitas antibiotik dari 60 jenis alga laut yang ada di dunia pada beberapa jenis bakteri uji. Jenis alga laut yang memiliki aktivitas antimikroba terhadap empat jenis bakteri yaitu Bacillus subtillis, Escherichia coli, Saccharomyces cerevisiae, dan Vibrio sp. adalah Gelidium amansii, Ploconium telfairiac, Heterosiphonia javanica, Rhodomela convercoides, Sargassum fusiforme, Sargassum thunbergii, Sargassum kjelmanianum, Laurencia sp., dan Ulva pertusa.

Sekitar 500 produk alami yang berasal dari rumput laut sudah diidentifikasi dan persentasi terbesar merupakan senyawa bioaktif yang merupakan hasil metabolisme sekunder. Berlainan dengan alga merah, alga coklat tidak menghasilkan senyawa metabolit berhalogen. Alga coklat umumnya menghasilkan senyawa komplek diterpenoid dan senyawa campuran terpenoid-aromatik yang mempunyai aktivitas biologi sebagai antibiotik. Alga biru hijau diketahui memproduksi senyawa non terpenoid dan banyak di antaranya bersifat toksik serta mengandung halogen terutama senyawa klorin. Senyawa ini juga mengandung nitrogen dalam bentuk amida atau indol yang memiliki aktivitas antibakteri dan antifungi (Takeshi et al., 2003, Atta-ur-Rahman \& Choudhary, 2001).

Burgess et al., (2003) dan Hellio et al., (2003) menyatakan dalam hasil penelitiannya bahwa alga jenis Ulva lactuca memiliki aktivitas sebagai senyawa antifouling, sedangkan beberapa alga lain seperti Fucus serratus, Fucus spiralis, Laminaria sp., Palmaria palmate, Corallina officinalis, Chondrus crispus, Poryphera umbilicas, Codium fragile sp. atlanticum, Mastocarpus stellatus, Leathesia difformis, Himanthalia elongate, Delesseria sanguinea, Dilesia carnosa, dan Halidrys siliquosa merupakan sumber bakteri epifitik yang dapat menghasilkan senyawa bioaktif.

\section{ALGA LAUT SEBAGAI PENGHASIL BIOETANOL DAN BIODIESEL}

Meskipun masih dalam tahap riset yang mendalam, potensi alga laut sebagai penghasil bioetanol dan biodiesel sangat menjanjikan di masa mendatang. Negara-negara maju seperti Amerika Serikat, Jepang, dan Kanada mentargetkan mulai tahun 2025 bahan bakar hayati (biofuel) bisa diproduksi dari budidaya cepat mikroalga yang tumbuh diperairan tawar/asin. Keuntungan lebih yang dapat diperoleh adalah tidak membutuhkan traktor seperti di darat, tanpa penyemaian benih, gas $\mathrm{CO}_{2}$ yang dihasilkan dapat dimanfaatkan sebagai bahan bakar dan panen yang terus-menerus dengan waktu tanam alga yang hanya 1 minggu (Soerawidjaja, 2005).

\section{ALGA LAUT SEBAGAI PUPUK ORGANIK}

Kandungan kimiawi yang terdapat dalam alga laut merupakan nutrien yang sangat penting bagi semua mahluk hidup termasuk tumbuh-tumbuhan, karena itu alga laut dapat dimanfaatkan sebagai sumber alternatif pengganti pupuk-pupuk pertanian.

Alga dapat digunakan sebagai pupuk organik karena mengandung bahan-bahan mineral seperti potasium dan hormon seperti auksin dan sitokinin yang dapat meningkatkan daya tumbuh tanaman untuk tumbuh, berbunga, dan berbuah. Pemanfaatan alga sebagai pupuk organik didukung pula oleh adanya sifat hidrokoloid pada alga laut yang dapat dimanfaatkan untuk penyerapan air (daya serap tinggi) dan menjadi substrat yang baik untuk mikroorganisme tanah (Augusto \& Pesso^a, 2003).

\section{SERAT ALAMI RUMPUT LAUT SEBAGAI BAHAN DASAR PENGGANTI PLASTIK}

Baru-baru ini, serat-serat alami (natural fibers) sangat populer dalam material komposit karena sifat-sifat yang dimilikinya. Bagaimanapun, ketika 


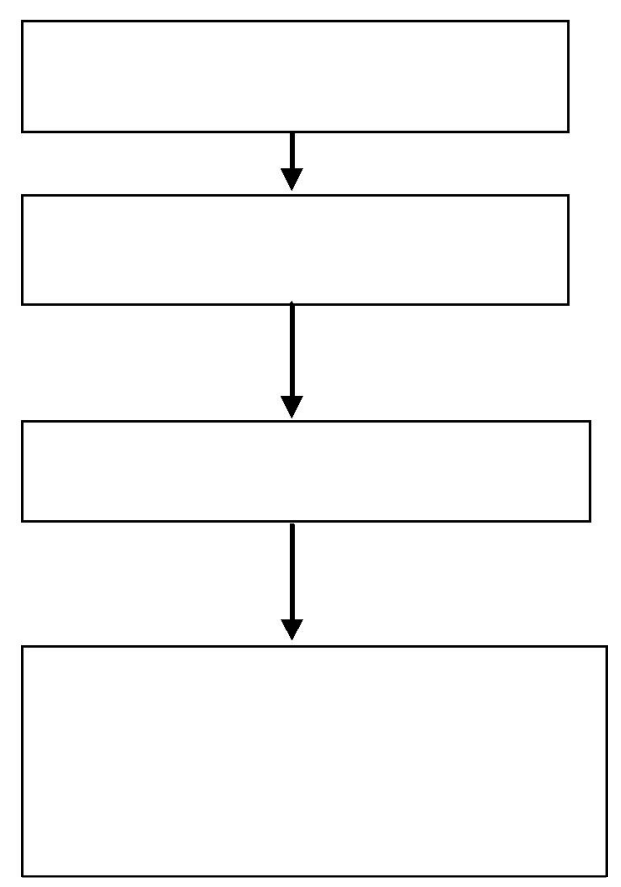

Gambar 1. Diagram alir pemanfaatan limbah rumput laut sebagai pengganti plastik.

serat ini dikombinasikan dengan polimer dari petrokimia, maka akan dihasilkan komposit yang tidak ramah terhadap lingkungan, karena serat alami tidak dapat dipisahkan dari material matriksnya. Oleh karena itu, kebutuhan akan material matriks yang juga terdiri atas bahan baku alami diperlukan. Sejak tahun 1998, German Aerospace Agency's Institute for Structural Mechanics in Braunschweig dan FNR (Fachagentur Nachwachsende Rohstoffe) telah membuat suatu riset bersama yang bertujuan untuk mengembangkan dan memasarkan material matriks berdasarkan bahan baku yang dapat diperbaharui (Sulzbach, 2003).

Material berbahan baku serat alami ini bersifat ramah lingkungan. Oleh karena itu, perlu dikembangkan untuk menggantikan material komposit yang berbahan baku material berupa duroplastik yang bersifat tidak dapat didaur ulang jika bahan ini mengandung serat gelas dan serat alami. Jika suatu material komposit terdiri atas serat gelas dan serat alami, maka komposit ini akan lebih mudah diinsinerasi dan dapat mengurangi bobot komposit yang diperlukan (Sulzbach, 2003). Gambar 1 di atas merupakan diagram alir pemanfaatan limbah rumput laut sebagai pengganti plastik.

\section{PENUTUP}

Indonesia merupakan negara kepulauan yang dua pertiga wilayahnya adalah laut. Potensi sumber daya alam kelautan yang berlimpah ini sangat memungkinkan untuk dapat mengembangkan salah satu biota laut berupa alga laut. Kekayaan laut di Indonesia meliputi berbagai macam jenis mikroalga dan makroalga yang kaya akan manfaat baik sebagai metabolit primer maupun sekunder. Di antara potensi tersebut alga laut memiliki banyak manfaat seperti sebagai sumber makanan, sumber senyawa alginat, adsorben logam berat, sumber senyawa bioaktif, penghasil bioetanol dan biodiesel, pupuk organik, dan juga sangat berpotensi untuk bahan dasar pengganti bahan plastik.

\section{DAFTAR PUSTAKA}

Anggadiredja, J. T., Zatnika, A., Purwoto, H., dan Istini, S. 2006. Rumput Laut. Jakarta: Penebar Swadaya.

Angka, S. L. dan Suhartono, M. T. 2000. Bioteknologi Hasil-hasil Laut. Bogor: PKSPL IPB.

Atta-ur-Rahman and M. Iqbal Choudhary.2001. Bioactive natural products as a potential sourceof new pharmacophores. A theory of memory. Pure Appl. Chem., Vol. 73, No. 3, p. 555-560.

Augusto da Costa1 A.C., and Pesso^a de Franc, Francisca. 2003. Cadmium Interaction with Microalgal Cells, Cyanobacterial Cells, and Seaweeds; Toxicology and Biotechnological Potential for Wastewater Treatment. Mar. Biotechnol. 5, p.149-156.

Burgess, J.G., Kenneth, G Boyd, Evelyn Armsttrong, Zhong Jiang, Liming Yan, Matz Berggren, Ulrika May, Tomy Pisacane and David Adam. 2003. The Development of a Marine Natural Product-based Antifouling Paint. Biofouling, 2003 Vol 19 (Supplement). p. 197-205. 
Harris and Ramelow. 1990. Binding of metal ions by particulate quadricauda. Environ. Sci. p. 627-652.

Hellio C., Jean-Philippe Marechal, Benoýt Ve'ron, Graham Bremer, Anthony S. Clare, and Yves Le Ga.2003. Seasonal variation of antifouling activities of marine algae from the brittany coast (France). Mar. Biotechnol. 6. p. 67-82.

Khotimchenko, Y.S. and Khotimchenko, M.Y. 2004. Healing and Preventive Effects of Calcium Alginate on Carbon Tetrachloride Induced Liver Injury in Rats. Mar. Drugs 2004, 2. p.108-122.

Konig GM, Wright AD, Sticher O, Angerhofer C.K., and Pezzuto M. 1994. Biological activities of selected marine natural product. Planta Med. 60(6) p. 532537.

Putra, Sinly Evan. 2006. Tinjauan Kinetika dan Termodinamika Proses. Adsorpsi lon Logam Pb, Cd, dan Cu oleh Biomassa Alga Nannochloropsis sp. Yang Dilmobilisasi Polietilamina-Glutaraldehid. Laporan Penelitian. Universitas Lampung. Bandar Lampung.

Satari, R. Potensi Pemanfaatan Rumput Laut Indonesia.1996. Jakarta: Pusat Penelitian dan Pengembangan Oseanologi LIPI. p. 152-177.
Soerawidjaja, Tatang H. 2005. Membangun Industri Biodiesel di Indonesia. Makalah IImiah Forum Biodiesel Indonesia. 16 Desember 2005. Bandung.

Sulzbach, Horst M. 2003. Innovative, Oleochemically based Polymers for Natural Fiber Reinforced Materials Towards $100 \%$ Plant-based Composites. Cognis Deutschland $\mathrm{GmbH}$, Henkelstraße 67, D40551 Düsseldorf.

Takeshi Sakai, Hitomi Kimura, Kaoru Kojima, Kazuo Shimanaka, Katsushige lkai, and Ikunoshin Kato. 2003. Marine Bacterial Sulfated Fucoglucuronomannan SFGM) Lyase Digests Brown Algal SFGM into Trisaccharides. Mar. Biotechnol. 5, p. 70-78.

Widjihati, R., A. Supriyono, dan Subintoro. 2004. Pengembangan Senyawa Bioaktif dari Biota Laut. Makalah pada Forum Bioteknologi Kelautan dan Perikanan, Pusat Riset Pengolahan Produk dan Sosial Ekonomi Kelautan dan Perikanan Departemen Kelautan dan Perikanan. Tanggal 25 Maret 2004. 13 pp.

Yunizal. 2004. Teknologi Pengolahan Alginat. Pusat Riset Pengolahan Produk dan Sosial Ekonomi Kelautan dan Perikanan. Jakarta. p. 2-3. 